\title{
ANALISIS ONLINE REVIEW TRIPADVISOR.COM TERHADAP MINAT PEMBELIAN PRODUK JASA AKOMODASI DI HOTEL MANHATTAN
}

\author{
TRIPADVISOR.COM REVIEW ONLINE ANALYSIS ON THE \\ INTEREST OF BUYING ACCOMMODATION SERVICES IN HOTEL \\ MANHATTAN
}

\author{
Rendy Sarudin ${ }^{1)}$ dan Achmad Ismail ${ }^{2)}$ \\ 1)Program Studi Hospitality, Universitas Bunda Mulia \\ 2)Peniliti di Pusat Studi Kemanusiaan dan Pembangunan (PSKP); \\ IImu Hubungan Internasional FISIP, Universitas Jakarta \\ Diterima Tanggal Bulan Tahun / Disetujui Tanggal Bulan Tahun
}

\begin{abstract}
Changes in tourist behavior have made hotel managers start to take advantage of technology in particular, ecommerce to further increase sales effectiveness, one way this is done is by providing online room reservation services (online booking). The growing online booking system has led to several travel review websites that help people interact, provide advice via the internet, including Tripadvisor. The purpose of this research is to analysis the influence of online review $(X)$ toward purchase intention $(Y)$ at Manhattan Hotel Jakarta. The population for the research is guest who booking the Manhattan Hotel in Online Travel Agent, Free Independent Traveler, Company as well as Group MICE (All source of booking) the sample is 99respondents. Respondents are selected using non-probability sampling, which is Purposive Sampling. This research uses single linear regression analysis. The result showed that the interest in buying the correlation to areview online Manhattan hotel in Jakarta clearly seen on the correlation Pearson is $0.720^{* *}$ that can be interpreted that availability of good relations rivalry online review and interest buy can be described as strong or positive and there is significant influence between online and review interest buy as much as $51.80 \%$ and $48.20 \%$ influenced by another factor.
\end{abstract}

Keywords: Online Review, Purchase Intention, Sales \& Marketing Department, Hotel

\begin{abstract}
ABSTRAK
Perubahan perilaku wisatawan membuat pengelola hotel mulai memanfaatkan teknologi khususnya $e$ commerce untuk lebih meningkatkan efektifitas penjualan, salah satu cara yang dilakukan adalah dengan menyediakan layanan reservasi kamar online (online booking). Sistem pemesanan online yang berkembang telah menghasilkan beberapa situs web ulasan wisata yang membantu orang berinteraksi, memberikan saran melalui internet, termasuk Tripadvisor. Tujuan dari penelitian ini adalah untuk menganalisis pengaruh online review (X) terhadap minat beli (Y) pada Hotel Manhattan Jakarta. Populasi dalam penelitian ini adalah tamu yang memesan Hotel Manhattan di Agen Travel Online, Free Traveler Mandiri, Perusahaan serta Group MICE (All source of booking) sampelnya adalah 99 responden. Responden dipilih dengan menggunakan non- probability sampling yaitu Purposive Sampling. Penelitian ini menggunakan analisis regresi linier tunggal. Hasil penelitian menunjukkan bahwa korelasi minat beli terhadap review online hotel Manhattan di Jakarta terlihat jelas pada korelasi Pearson sebesar $0,720 * *$ yang dapat diartikan bahwa ketersediaan review online persaingan hubungan baik dan minat beli dapat dikatakan kuat atau positif. dan terdapat pengaruh yang signifikan antara minat beli online dan review sebesar $51.80 \%$ dan $48.20 \%$ dipengaruhi oleh faktor lain.
\end{abstract}

Kata Kunci: Review Online, Niat Membeli, Sales \& Marketing Department, Hotel 


\section{PENDAHULUAN}

Perkembangan ilmu pengetahuan dan teknologi yang semakin pesat pada awal abad 20 telah melahirkan teknologi informasi dan proses produksi yang dikendalikan secara otomatis atau yang disebut dengan industri 4.0. Ini merupakan tren otomatisasi dan pertukaran data dalam teknologi manufaktur Industri 4.0 memberi dampak yang besar secara global pada industry pariwisata tak terkecuali di Indonesia.

Industri pariwisata sendiri saat ini tidak lepas dari perkembangan teknologi tersebut. Cara-cara "berwisata lama" perlahan mulai ditinggalkan dan adanya teknologi seperti ketersediaan wi-fi, sinyal 4G yang kuat, serta beragam travel apps sangat dimanfaatkan oleh wisatawan. Sebagai contoh yaitu dalam merencanakan perjalanan, wisatawan tidak perlu pergi ke travel agent untuk membeli tiket atau sekedar memesan kamar di hotel. Wisatawan mampu melakukan transaksi dengan mengunduh aplikasi online travel agent dari gadget lalu klik, dan sudah bisa mendapat apa yang kita butuhkan.

Perubahan perilaku wisatawan tersebut membuat para pengelola hotelmulai memanfaatkan teknologi khususnya, $e$ commerce untuk lebih meningkatkan efektivitas penjualan, salah satu cara yang dilakukan adalah menyediakan pelayanan reservasi kamar secara online (online booking). Tingginya angka reservasimelalui online khususnya pada travel agent, merupakan sebuah peluang yang bisa berdampak positif atau negatif karena konsumen cenderung untuk mencari informasi mengenai produk atau jasa yang akan mereka beli di internet untuk mengurangi resiko ketidakpastian (Peterson dan Merino, 2003). Sebelum konsumen melakukan pembelian pada sebuah situs $e$ commerce, biasanya mereka akan melihat informasi mengenai produk dari tinjauan secara online sebagai dasar untuk menilai apakah mereka akan melakukan pembelian (www.tirto.id, 2016).

Lembaga E-marketer mengatakan bahwa $61 \%$ konsumen terpengaruh dengan review, blogs dan sharing review platform sejenisnya, sumber lain dalam laporan dari CNNIC ada sebesar 53,9\% konsumen akan melakukan pencarian berdasarkan pada pendapat atau komentar mengenai suatu produk yang akan dibeli, hasilnya adalah $78,9 \%$ akan melihat komentar-komentar mengenai produk dan $90 \%$ konsumen akan membuat komentar mengenai suatu produk (Samuel dan Lianto, 2014).

Memang, sistem online booking yang terus berkembang memunculkan beberapa website travel review yang membantu orangorang untuk berinteraksi, memberikan saran melalui internettermasuk salah satu di dalamnya yaitu Tripadvisor. TripAdvisor merupakan salah satu situs perjalanan terbesar di dunia, memungkinkan wisatawan untuk merencanakan dan mendapatkan perjalanan yang sempurna (Fergian, 2018). TripAdvisor pula dibentuk sebagai situs pencarian hotel dan tempat wisata yang paling sering dikunjungi pada tahun 2013. TripAdvisor pula merupakan situs perjalanan online terpopuler kedua dengan 48,5 juta pengguna di dunia pada tahun 2013 setelah booking.com dengan 108 juta pengguna (Fergian, 2018). Hal tersebut diperkuat oleh data dari reviewtracker.com dalam gambar sebagai berikut: 


\section{Table 1. Distribution of Hotel Reviews}

\section{Distribution of Hotel Reviews}

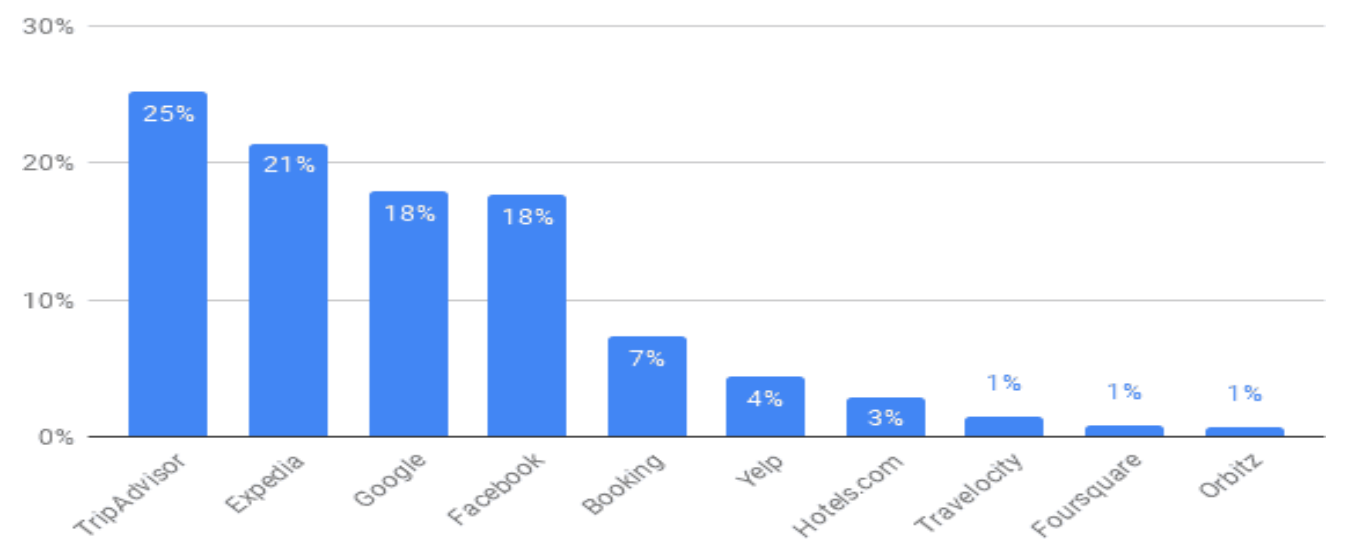

(Sumber: reviewtrackers.com, 2018)

Berdasarkan riset yang dilakukan oleh Review Trackers artinya bahwa wisatawan mempercayakan TripAdvisor sebagai situs review utama ketika akan melakukan pembelian hotel. TripAdvisor didirikan pada Februari tahun 2000 di Needham, Massachusetts, Amerika Serikat. Pada awalnya TripAdvisor merupakan sebuah situs B2B (business to business) yang tujuannya adalah untuk mempertemukan produsen dengan produsen, seiring berjalannya waktu situsini dimanfaatkan oleh para komunitas traveller untuk berbagi pengalaman mereka dari situlah TripAdvisor berubah menjadireview site untuk pariwisata merupakan salah satu media online hotel review yang umum. Selain terdapat isi ulasan mengenai sebuah hotel tetapi melalui situs TripAdvisor pun dapat ditemukan foto-foto, harga dan keterangan fasilitas hotel yanglangsung di upload oleh pihak situs TripAdvisor secara official atau langsung diupload oleh orang yang mengulas.

Manhattan Hotel merupakan salah satu hotel yang diulas dalam TripAdvisor. Manhattan Hotel adalah Hotel lokal chain yang berada naungan Sunlake Group of Hotel yang berlokasi dikawasan Kuningan, Jakarta Selatan, dimana lokasinya strategis, mudah diakses, dan harga yang kompetitif. Keunggulan tersebut membuat Manhattan Hotel menjadi salah satu hotel yang memiliki nilai lebih diantara pesaing.
Berdasarkan hasil wawancara dengan Eva Juwita Selaku Head of Sales-MICE Manhattan Hotel, mulai tahun 2018, Hotel Manhattan telah mengubah strategi penjualan kamar dengan mengalokasikan 50 $\%$ okupansi kamar ke beberapa online travel agent yang telah menandatangani nota kesepakatan. Menurut data dari Hotel Manhattan mengenai reservasi kamar pada tahun 2018, angka rata-rata perhari $59.40 \%$ dari keseluruhan okupansi hotel melakukan transaksi melalui online travel agent.

Dikutip dari website Tripadvisor.com mengenai penilaian melalui empat aspek yaitu kualitas meliputi penilaian lingkaran atau point untuk menilai keseluruhan dari property, kebaruan dari ulasan baru lebih bernilai daripada ulasan lama karena memberikan gambaran lebih akurat tentang pengalaman terbaru di properti tersebut. Ini berarti ulasan lama (positif maupun negatif) memiliki pengaruh lebih kecil dalam menentukan peringkat properti dibandingkan ulasan yang baru ditulis. Meskipun tidak berpengaruh besar dalam menentukan peringkat, ulasan lama tetap terlihat di bagian Ikhtisar setiap daftar dan dalam riwayat ulasan property.

Jumlah ulasan adalah indikator utama tentang properti bagi pengguna TripAdvisor, pengguna TripAdvisor biasanya membaca beberapa ulasan untuk membantu membentuk opini yang seimbang tentang property dan konsistensi 
seperti ulasan positif lebih banyak dari pada ulasan negative, ulasan baru lebih diutamakan dan jika ada ulasan baru harus segara dibalas lebih banyak ulasan akan membantu membangun keyakinan secara lebih cepat

Faktor tersebut saling berkaitan seiring waktu untuk menentukan Peringkat Popularitas properti. Misalnya, kualitas dan jumlah ulasan dari waktu ke waktu memberikan gambaran tentang konsistensi masing-masing properti. Properti yang konsisten memiliki ulasan positif akan berperingkat lebih tinggi dibandingkan properti dengan jumlah ulasan positif dan negatif yang sama. Demikian juga, kebaruan dan jumlah berkaitan erat dengan ulasan baru dalam jumlah besar akan bernilai lebih tinggi daripada ulasan lama.

Identifikasi masalah dari uraian di atas bahwa kehadiran Tripadvisor.com sebagai online review menjadi salah satu penyebab naiknya okupansi (minat beli) Manhattan Hotel Jakarta. Lantas, penulis ingin mengambil rumusan masalah bagaimana pengaruh online review terhadap okupansi (minat beli) di Manhattan Hotel Jakarta?. Artikel ini berargumen bahwa kehadiran Tripadvisor.com memiliki pengaruh positif terhadap okupansi atau minat beli dari Manhattan Hotel Jakarta. Artikel ini bertujuan untuk mengkaji tingginya angka reservasi hotel via online travel agent di Manhattan Hotel. Sebelum melakukan reservasi, calon tamu akan melihat review atau ulasan dari tamu sebelumnya yang menginap di Manhattan Hotel baik ulasan yang positive maupun ulasan negatif. Sehingga dapat diketahui apakah online review di TripAdvisor mempengaruhi minat beli di Manhattan Hotel. Sehingga dengan mengetahui adanya pengaruh atau tidak, maka pihak hotel dapat membuat kebijakan yang lebih baik dalam mengoptimalisasi pendapatan khususnya dari pemesanan kamar.

\section{METODE PENELITIAN}

Metode penelitian yang dipakai dalam artikel ini ialah pendekatan penelitian kuantitatif. Penelitian kuantitatif disebut juga dengan penelitian positivis (positivist) yang menekankan pada pengujian teori - teori melalui pengukuran varibel - varibel penelitian dengan angka dan melakukan analisis data dengan pengolahan data statistik (Sugiarto, 2015). Metode Kuantitatif yang digunakan oleh penulis pada penelitian ini, menggunakan metode penelitian survei. Penelitian survei dilakukan apabila peneliti melakukan kegiatan pengumpulan data secara langsung ke lapangan dengan cara survei kepada responden yang ditujunya. Dalam hasil penelitian ini, Creswill (2014) berpendapat bahwa penelitian kuantitatif memiliki sifat asli yang obyektif dari pengamatan dan pengukuran empiris menggunakan beberapa metode Analisa data yang terdiri dari: Uji Validitas, Uji Reliabilitas, Uji Deskriptif,Uji Korelasi Pearson (Pearson-ProductMoment), Regresi Linear Sederhana, Koefisien Determinasi dan Uji $\mathrm{T}$ (Uji Hipotesis).

Subjek Penelitian (populasi dan sampling) dalam artikel ini total room night sold selama satu bulan yaitu pada bulan Juni 2019 sebanyak 6838 pax yang diakumulasikan dari jumlah total room sold selama bulan Juni 2019 sebanyak 3452 malam. Sugiono (2004; 90) menerangkan bahwa populasi adalah wilayah generalisasi yang terdiri atas obyek atau subyek yang mempunyai kualitas dan karakteristis tertentu yang ditetapkan oleh peneliti untuk mempelajari dan kemudian ditarik kesimpulan.

Dalam hal teknik penarikan sampel dilakukan dengan sifat non-probability sampling atau convenience sampling yaitu dengan memilih orang yang paling mudah ditemui sebagaimana dijelaskan oleh Sugiyono (2016) bahwa Non-probability sampling adalah Teknik pengambilan sampel yang tidak memberi peluang atau kesempatan sama bagi setiap unsur atau anggota populasi untuk dipilih menjadi sampel. Teknik sampel ini meliputi: sampling sistematis kuota, aksidental, purposive, jenuh, dan snowball 
Berdasarkan jenis - jenis Teknik non-probability sampling tersebut, maka metode sampling yang tepat digunakan dalam artikel ini adalah purposivesampling. Sugiyono (2016) menjelaskan bahwa purposive sampling adalah sebuah teknik pengambilan sampel sumber data dengan pertimbangan tertentu. Oleh karenanya, purposive sampel dalam penelitian ini hanya sampel yang pernah mendapatkan pengalaman menginap di Manhattan Hotel dengan cara memesannya menggunakan Online Travel Agent

Dari jumlah populasi yang mewakili Purposive sampling sebanyak 99 orang, maka dapat ditentukan jumlah sample yang mewakili dengan menggunakan rumus slovin sebagai berikut:

$$
\mathrm{n}=\frac{N}{1+N e^{2}}
$$

dengan keterangan:

$\mathrm{n}$ : jumlah sampel,

$\mathrm{N}$ : jumlah populasi,

e: nilai toleransi error, nilai $10 \%$

ditetapkan sebagai batas toleransi error

Sementara teknik analisis data dalam penelitian ini menggunakan fiturperhitungan dari aplikasi SPSS 25 (Statistical Product and Service Solutions). SPSS merupakan suatu program komputer statistik yang mampu mengolah/memproses data statistik secara cepat dan tepat, untuk mendapatkan berbagai hasil/ output yang dibutuhkan peneliti.

Adapun beberapa tes dan analisa data yang dilakukan berupa:

\section{Uji Validitas}

Untuk mementukan tingkatvaliditas dari setiap pernyataan maka perlu adanya nilai standard sebagai perbandingan denga nilai yang didapat kan pada hasil output data olahan SPSS

25. Nilai tersebut adalah nilai $r$, yang terdiri dari nilai $r_{\text {tabel }}$ dan $r_{\text {hitung. }}$ Pada uji vaiditas penelitian ini, ditetapkan sebuah standar sebagai perbandingan dengan ditunjukkan dengan nilai $r_{\text {tabel }}$ dan nilai $\mathrm{r}_{\text {hitung }}$ yang didapatkan dari hasil olah data uji validitas. Penilianan ini meliputi memiliki patokan sebagai berikut (Sugiyono, 2015):
- Bila $\mathrm{r}_{\text {tabel }}>\mathrm{r}_{\text {hitung, maka dapat }}$ dikatakan pernyataan di kusioner dikatakan valid

- Bila $\mathrm{r}_{\text {tabel }}<\mathrm{r}_{\text {hitung, maka dapat }}$ dikatakan pernyataan di kusioner dikatakan tidak valid

Pada penelitian ini, diketahui bahwa dengan:

$$
\mathrm{n} \text { : sampel sebanyak } 99
$$$$
\text { dengan rumus degree of }
$$

freedom, sebagai berikut :

$$
\mathrm{df}=\mathrm{n}-2
$$

\section{Uji Reliabilitas}

Penenlitian ini perlu dilakukan uji reliabilitas. Menurut Arikunto (2010:87) mengemukakan bahwa reliabilitas merupakan tingkat keajegan atau dapat dipercaya (konsistensi) suatu angket, dengan kata lain sejauh mana angket dapat dipercaya untuk menghasilkan skor yang ajeg atau tidak berubah-ubah.

\section{Uji Statistik Deskriptif (Mean)}

Menurut Singgih (2005:179) statistik deskriptif lebih berhubungan dengan pengumpulan dan peringkasan data, serta penyajian hasil peringkasan tersebut. Sedangkan data statistik, yang biasa diperoleh dari sensus, survei atau pengamatan lainnya, umumnya masih acak, mentah dan tidak terorganisir dengan baik. Dimana, data tersebut harus diringkas dengan baik dan teratur, baik dalam bentuk tabel atau persentaasi grafis, sebagai dasar untuk berbagai pengambilan keputusan, dalam statistik deskriptif data akan diolah untuk mendapatkan Mean/ hasil rata-rata setiap sub variabel bebas maupun terikatnya.

\section{Uji Korelasi Pearson (Pearson Product- Moment)}

Metode analisis data menggunakan analisis pearson produk momen. Metode analisis person adalah suatu bentuk rumus yang digunakan untuk mencari hubungan antara dua variabel, yaitu variabel bebas atau independent variable dan variabel terikat atau dependent variable. Di manaumumnya variabel terikat disebut variabel $\mathrm{Y}$ dan variabel bebas disebut variabel $\mathrm{X}$, dimana variabel bebas ini merupakan 
pemberian dari hasil suatu observasi sehingga variabel bebas tersebut tidak lagi Random atau acak. (Cristianus 2009)

\section{Kofisien Determinasi}

Menurut Kusmayadi (2004) Kofisien Determinasi adalah mengkuadratkan koefisien korelasi dan dikalikan $100 \%$. Rumusan koefisien Determinasinya adalah:

$$
k d=r^{2} \times 100 \%
$$

\section{Keterangan koefisien determinasi:}

$\mathrm{kd}=$ Koefisien determinasi

$\mathrm{r}=$ Koifisien korelasi yang didapatkan

Analisis ini bertujuan untuk melihat bagaimana pengaruh online review terdadap Minat Beli produk jasa yang ada di Manhattan Hotel Jakarta

\section{Regresi Linier Sederhana}

Menurut Kusmayadi (2004) regresi linier sederhana adalah regresi linier yang menganalisis hubungan antara satu variabel bebas dan satu variabel tak bebas (terikat). Maka analisis ini dilakukan apabila seseorang ingin mengetahui apakah variabel bebas dapat menyebabkan suatu kejadian, yaitu variabel terikat. Dengan melakukan analisis regresi, dapat diputuskan apakah variabel terikat akan meningkat atau menurun. Rumus menurut Kusmayadi (2004) untuk menghitung persamaan regresi linier sederhana :

$\mathbf{Y}=\mathbf{a}+\mathbf{b X}$

Keterangan:

$\mathrm{Y}=$ Variabel dependen (nilai yang diprediksikan)

$\mathrm{X}=$ Variabel independen

$\mathrm{a}=$ Konstanta (nilai $\mathrm{Y}$ apabila $\mathrm{X}=0$ )

$\mathrm{b}=$ Koefisien regresi (nilai peningkatan jika bernilai positif, penurunan jika bernilai negatif)

\section{Uji T (Parsial)}

Uji t (t-test) melakukan pengujian terhadap koefisien regresi secara parsial, pengujian ini dilakukan untuk mengetahui signifikansi peran secara parsial antara variabel independen terhadap variabel dependen dengan mengasumsikan bahwa variabel independen lain dianggap konstan.

\section{HASIL DAN PEMBAHASAN}

Uji validitas variabel online review $(\mathrm{X})$ 


\section{Item-Total Statistics}

\begin{tabular}{|c|c|c|c|c|}
\hline & $\begin{array}{r}\text { Scale Mean if } \\
\text { Item Deleted }\end{array}$ & $\begin{array}{l}\text { Scale Variance } \\
\text { if Item Deleted }\end{array}$ & $\begin{array}{l}\text { Corrected Item- } \\
\text { Total } \\
\text { Correlation } \\
\end{array}$ & $\begin{array}{c}\text { Cronbach's } \\
\text { Alpha if Item } \\
\text { Deleted } \\
\end{array}$ \\
\hline $\begin{array}{l}\text { Review yang ada di Trip } \\
\text { Advisor berkaitan dengan } \\
\text { hotel }\end{array}$ & 45.68 & 22.568 & .284 & .766 \\
\hline $\begin{array}{l}\text { Review yang ada di Trip } \\
\text { Advisor sangat bermanfaat } \\
\text { bagi pelanggan }\end{array}$ & 45.27 & 21.772 & .441 & .753 \\
\hline $\begin{array}{l}\text { Review Trip Advisor } \\
\text { mencerminkan informasi } \\
\text { terkini terkait hotel }\end{array}$ & 45.41 & 21.572 & .442 & .752 \\
\hline $\begin{array}{l}\text { Review yang diunggah Trip } \\
\text { Advisor sangat penting }\end{array}$ & 45.51 & 20.212 & .613 & .734 \\
\hline $\begin{array}{l}\text { Tertarik kepada hotel yang } \\
\text { memiliki jumlah ulasan } \\
\text { yang lebih banyak }\end{array}$ & 45.39 & 20.731 & .510 & .744 \\
\hline $\begin{array}{l}\text { Jumlah Review } \\
\text { meningkatkan keinginan } \\
\text { untuk memesan hotel }\end{array}$ & 45.45 & 20.169 & .534 & .740 \\
\hline
\end{tabular}

\begin{tabular}{lllll}
\hline $\begin{array}{l}\text { Memperhatikan review } \\
\text { yang bersifat positif }\end{array}$ & 45.66 & 21.942 & .246 & .774 \\
\hline $\begin{array}{l}\text { Memperhatikan hotel yang } \\
\text { memperoleh review positif } \\
\text { yang lebih banyak }\end{array}$ & 45.46 & 21.394 & .439 & .752 \\
\hline $\begin{array}{l}\text { Menurut pelanggan ulasan/ } \\
\text { review yang singkat sama } \\
\text { pentingnya dengan yang } \\
\text { detail }\end{array}$ & 45.96 & 20.468 & .307 & .774 \\
\hline $\begin{array}{l}\text { Menurut pelanggan ulasan/ } \\
\text { review yang detail akan } \\
\text { lebih menarik perhatian }\end{array}$ & 45.38 & 21.239 & .490 & .748 \\
\hline $\begin{array}{l}\text { Review dari orang yang } \\
\text { terkenal akan lebih menarik }\end{array}$ & 45.54 & 21.006 & .352 & .762 \\
\hline $\begin{array}{l}\text { Review dari orang yang } \\
\text { mengerti industri hotel akan } \\
\text { lebih menarik }\end{array}$ & 45.51 & 21.150 & .395 & .756 \\
\hline
\end{tabular}

Sumber: olahan data peneliti, 2019 
Uji Validitas Menurut Sugiyono (2017) menyatakan bahwa jika hasil $\mathrm{r}_{\text {hitung }}>$ $\mathrm{r}_{\text {tabel }}$ maka dikatakan valid dan jika $\mathrm{r}_{\text {hitung }}<$ $\mathrm{r}_{\text {tabel }}$ maka dinyatakan tidak valid penelitian ini menggunakan taraf signifikasi sebesar $10 \%$ atau 0,1663 .

Berdasarkan hasil tabel di atas dapat dilihat bahwa nilai yang ada pada corrected item-total correlation menunjukan angka yang lebih besar dari $\mathrm{r}_{\text {tabel }}$ yaitu 0,1663 . Jadi dapat disimpulkan variabel X1 sampai dengan X12 dinyatakan valid, hal ini dikarenakan responden dapat memahami dan mengerti dengan pernyataan didalam kuesioner yang telah disebar.

Uji validitas variabel minat beli $(\mathbf{Y})$

\section{Item-Total Statistics}

\begin{tabular}{|c|c|c|c|c|}
\hline & $\begin{array}{r}\text { Scale Mean if } \\
\text { Item Deleted }\end{array}$ & $\begin{array}{l}\text { Scale Variance if } \\
\text { Item Deleted }\end{array}$ & $\begin{array}{l}\text { Corrected Item- } \\
\text { Total Correlation }\end{array}$ & $\begin{array}{l}\text { Cronbach's Alpha } \\
\text { if Item Deleted }\end{array}$ \\
\hline $\begin{array}{l}\text { Tripadvisor membangkitkan } \\
\text { kesadaran keunggulan dan } \\
\text { keunikan Manhattan hotel, }\end{array}$ & 45.22 & 27.624 & .638 & .899 \\
\hline $\begin{array}{l}\text { Tripadvisor membangun citra } \\
\text { merek yang positif di social } \\
\text { media }\end{array}$ & 45.09 & 27.308 & .615 & .901 \\
\hline $\begin{array}{l}\text { Tripadvisor memberikan } \\
\text { informasi yang memadai }\end{array}$ & 45.14 & 27.204 & .724 & .895 \\
\hline $\begin{array}{l}\text { Tripadvisor memberikan } \\
\text { informasi special occation } \\
\text { Imelalui social media atau web }\end{array}$ & 45.12 & 27.026 & .685 & .897 \\
\hline $\begin{array}{l}\text { Informasi dari Tripadvisor } \\
\text { memberikan rasa ketertarikan }\end{array}$ & 45.20 & 28.183 & .622 & .900 \\
\hline $\begin{array}{l}\text { Informasi Tripadvisor } \\
\text { memberikan rasa } \\
\text { keingintahuan produk jasa } \\
\text { Manhattan Hotel }\end{array}$ & 45.11 & 27.732 & .657 & .898 \\
\hline $\begin{array}{l}\text { Melalui Tripadvisor, saya } \\
\text { membandingkan produk dan } \\
\text { jasa Manhattan Hotel }\end{array}$ & 45.11 & 28.100 & .601 & .901 \\
\hline $\begin{array}{l}\text { Melalui Tripadvisor, dapat } \\
\text { membandingkan harga serta } \\
\text { kualitas produk Hotel }\end{array}$ & 45.01 & 29.112 & .488 & .906 \\
\hline $\begin{array}{l}\text { Melihat review, menumbuhkan } \\
\text { keyakinan dan minat } \\
\text { Manhattan Hotel. }\end{array}$ & 45.25 & 28.476 & .585 & .902 \\
\hline
\end{tabular}




\begin{tabular}{|c|c|c|c|c|}
\hline $\begin{array}{l}\text { Melalui dengan vitur berbagi } \\
\text { foto lebih yakin melihat } \\
\text { fasilitas yang ada di Manhattan } \\
\text { Hotel }\end{array}$ & 45.03 & 27.213 & .723 & .895 \\
\hline $\begin{array}{l}\text { Garansi dan potongan harga } \\
\text { melalui Tripadvisor, membuat } \\
\text { rminat untuk membelinya. }\end{array}$ & 45.03 & 28.009 & .636 & .899 \\
\hline $\begin{array}{l}\text { Melalui Tripadvisor pelanggan } \\
\text { mudah melakukan pembelian } \\
\text { ulang }\end{array}$ & 45.12 & 27.618 & .647 & .899 \\
\hline
\end{tabular}

Uji Validitas Menurut Sugiyono (2017) menyatakan bahwa jika hasil $\mathrm{r}_{\text {hitung }}>$ $\mathrm{r}_{\text {tabel }}$ maka dikatakan valid dan jika $\mathrm{r}_{\text {hitung }}<$ $r_{\text {tabel }}$ maka dinyatakan tidak valid penelitian ini menggunakan taraf signifikasi sebesar $10 \%$ atau 0,1663 . Berdasarkan hasil tabel di atas dapat dilihat bahwa nilai yang ada pada corrected item-total correlation menunjukan angka yang lebih besar dari $r_{\text {tabel }}$ yaitu 0,1663. Jadi dapat disimpulkan variabel Y1 sampai dengan Y12 dinyatakan valid, hal ini dikarenakan responden dapat memahami dan mengerti dengan pernyataan didalam kuesioner yang telah disebar.

\section{Uji reliabilitas variabel online review $(\mathbf{X})$}

\begin{tabular}{|c|c|c|c|}
\hline \multicolumn{4}{|c|}{ Case Processing Summary } \\
\hline & & & $\%$ \\
\hline \multirow{3}{*}{ Cases } & Valid & 99 & 100.0 \\
\hline & Excluded $^{\mathrm{a}}$ & 0 & .0 \\
\hline & Total & 99 & 100.0 \\
\hline
\end{tabular}

a. Listwise deletion based on all variables in the procedure.

\begin{tabular}{ll}
\hline \multicolumn{2}{l}{ Reliability Statistics } \\
\hline Cronbach's \\
Alpha & N of Items \\
\hline .771 & 12 \\
\hline
\end{tabular}

(Sumber: olahan data peneliti, 2019)

Menurut Sugiyono (2015:349) suatu pernyataan di dalam kuesioner dinyatakan reliabel jika cronbach's alpha >0,60. Berdasarkan hasil tabel di atas dapat dilihat bahwa cronbach's alpha yang didapat sebesar 0,771 .
Maka dapat disimpulkan bahwa pernyataan pada variabel $X$ dinyatakan sangat realiabel yang artinya bahwa 99 responden dapat berhasil menjawab secara konsisten pada 12 instrumen pernyataan yang diajukan.

\section{Uji reliabilitas variabel minat beli (Y)}

\begin{tabular}{|c|c|c|c|}
\hline \multicolumn{4}{|c|}{ Case Processing Summary } \\
\hline & & & $\%$ \\
\hline \multirow{3}{*}{ Cases } & Valid & 99 & 100.0 \\
\hline & Excluded $^{\mathrm{a}}$ & 0 & .0 \\
\hline & Total & 99 & 100.0 \\
\hline
\end{tabular}

a. Listwise deletion based on all variables in the procedure.

\begin{tabular}{ll}
\hline Reliability Statistics \\
\hline Cronbach's \\
Alpha & N of Items \\
\hline .907 & 12 \\
\hline
\end{tabular}

(Sumber: olahan data peneliti, 2019)

Menurut Sugiyono (2015:349) suatu pernyataan di dalam kuesioner dinyatakan reliabel jika cronbach's alpha >0,60. Berdasarkan hasil tabel di atas dapat dilihat bahwa cronbach's alpha yang didapat sebesar 0,908. Maka dapat disimpulkan bahwa pernyataan pada variabel $\mathrm{Y}$ dinyatakan sangat realiabel yang artinya bahwa 99 responden dapat berhasil menjawab secara konsisten pada 12 instrumen pernyataan yang diajukan.

\section{Analisis Deskriptif Variabel Online Review (X)}




\begin{tabular}{ccc}
\hline Variable & $\begin{array}{c}\text { Average } \\
\text { (mean) }\end{array}$ & Result \\
\hline X1 & 4.38 & $\begin{array}{c}\text { Very } \\
\text { Good }\end{array}$ \\
\hline X2 & 4.27 & $\begin{array}{c}\text { Very } \\
\text { Good }\end{array}$ \\
\hline X3 & 4.26 & $\begin{array}{c}\text { Very } \\
\text { Good }\end{array}$ \\
\hline X4 & 4.24 & $\begin{array}{c}\text { Very } \\
\text { Good }\end{array}$ \\
\hline X5 & 4.20 & $\begin{array}{c}\text { Very } \\
\text { Good }\end{array}$ \\
\hline X6 & 4.19 & Good \\
\hline X7 & 4.15 & Good \\
\hline X8 & 4.15 & Good \\
\hline X9 & 4.12 & Good \\
\hline X10 & 4.00 & Good \\
\hline X12 & 3.98 & Good \\
\hline 3otal & 4.13 & Good \\
\hline Good \\
\hline X1
\end{tabular}

Sumber: olahan data peneliti, 2019

Berdasarkan tabel diatas dapat disimpulkan bahwa Isi dari ulasan / review yang ada di TripAdvisor sangat bermanfaat bagi pelanggan untuk menentukan pilihan menginap dengan perolehan 4,38 berpengaruh sangat baik atau kuat kepada para pelanggan untuk melihat review atau ulasan sebagai tolak ukur untuk mentukan pilihan menginap.

Menurut pelanggan ulasan/ review yang singkat sama pentingnya dengan yang detail dengan perolehan 3,70 berpengaruh baik tetapi tidak begitu kuat karena dalam review singkat pelanggan tidak bisa mendapatkan informasi yang mendalam menegenai suatu hotel.

Secara keleluruahn rata- rata variable Online Review adalah 4.13 menurut Sudjana adalah kuat atau baik dalam meberikan informasi kepada pelanggan untuk memilih Manhattan Hotel sebagai salah satu pilihan untuk menginap.

Analisis Deskriptif Variabel Minat Beli (Y)

\begin{tabular}{ccl}
\hline Variable & $\begin{array}{c}\text { Average } \\
(\text { mean })\end{array}$ & Result \\
\hline Y1 & 4,21 & $\begin{array}{c}\text { Very } \\
\text { High }\end{array}$ \\
\hline Y2 & 4,19 & High \\
\hline Y3 & 4,19 & High \\
\hline Y4 & 4,13 & High \\
\hline Y5 & 4,11 & High \\
\hline Y6 & 4,11 & High \\
\hline Y7 & 4,10 & High \\
\hline Y8 & 4,10 & High \\
\hline Y9 & 4,08 & High \\
\hline Y10 & 4,02 & High \\
\hline Y11 & 4,00 & High \\
\hline Y12 & 3,97 & High \\
\hline Total & 4.10 & High \\
\hline
\end{tabular}

Sumber: olahan data peneliti, 2019

Berdasarkan tabel diatas dapat disimpulkan bahwa Melalui Tripadvisor, pelanggan dapat membandingkan harga serta kualitas produk Manhattan Hotel menjadi point yang berpengaruh sangat kuat atau sangat tinggi dalam minat beli produk jasa Manhattan Hotel dengan peolehan 4,21 . 
Berdasarkan hasil kuisioner Melihat review Manhattan Hotel melalui Tripadvisor, menumbuhkan keyakinan dan minat pelanggan akan produk dan jasa Manhattan Hotel memiliki perolehan 3,97 berpengaruh tinggi terhadap minat belitetapi tidak terlalu kuat dalam menyakinkan pelanggan untuk menjadikan Manhattan Hotel sebagai pilihan utama penulis memperkirakan ada faktor lain seperti harga ataupun fasilitas yang lebih memadai yang mebuat pelanggan tidak terlalu yakin dengan Manhattan Hotel.
Secara keleluruahn rata- rata variable Minat Beli adalah 4.10 menurut Sudjana adalah kuat atau baik dalam minat beli pelanggan untuk penggunkan produk jasa akomodasi di Manhattan Hotel.

\section{Pearson Correlation Test (Pearson Product-Moment)}

Uji Korelasi ini bertujuan untuk mencari korelasi antara Sub Variabel X (online review) terhadap Variabel Y (minat beli).

\begin{tabular}{|c|c|c|c|}
\hline \multicolumn{4}{|c|}{ Correlations } \\
\hline & & $\begin{array}{l}\text { ONLINE_RE } \\
\text { VIEW }\end{array}$ & $\begin{array}{c}\text { MINAT_BE } \\
\text { LI }\end{array}$ \\
\hline \multirow{3}{*}{$\begin{array}{l}\text { ONLINE_REVIE } \\
\mathrm{W}\end{array}$} & Pearson Correlation & 1 & $.720^{* * *}$ \\
\hline & Sig. (2-tailed) & & .000 \\
\hline & $\mathrm{N}$ & 99 & 99 \\
\hline \multirow[t]{3}{*}{ MINAT_BELI } & Pearson Correlation & $.720^{* *}$ & 1 \\
\hline & Sig. (2-tailed) & .000 & \\
\hline & $\mathrm{N}$ & 99 & 99 \\
\hline
\end{tabular}

Berdasarkan tabel tersebut hasil korelasi di atas menunjukan bahwa online review memiliki hubungan terhadap minat beli Hotel Manhattan sebesar 0,720. Menurut pedoman untuk memberikan interpretasi koefisien korelasi dari Sugiyono (2015:231) korelasi dengan angka 0,720 menunjukan bahwa hubungan yang dimiliki oleh online review terhadap minat beli dapat dikategorikan dalam tingkat hubungan yang kuat dan memilikihubungan yang nyata atau signifikan.

Uji Koefisien Determinasi

\begin{tabular}{lcccr}
\hline \multicolumn{5}{c}{ Model Summary } \\
\hline Model & $\mathrm{R}$ & R Square & $\begin{array}{c}\text { Adjusted R } \\
\text { Square }\end{array}$ & $\begin{array}{c}\text { Std. Error of } \\
\text { the Estimate }\end{array}$ \\
\hline 1 & $.720^{\mathrm{a}}$ & .518 & .513 & 3.99519 \\
\hline a. Predictors: (Constant), ONLINE_REVIEW \\
\hline
\end{tabular}

Sumber: olahan data peneliti, 2019

Berdasarkan tabel tersebut dapat diketahui bahwa koefisien determinasi sebesar 0,518. Sesuai dengan rumus $\mathrm{KD}=\mathrm{r}^{2}$ x 100\%, sehingga dapat diperoleh bahwaKD Online Review terhadapat Minat beli sebesar $51,80 \%$. Hal ini dapat diartikan bahwa variabel Online Review memiliki kontribusi $51,80 \%$ terhap dapat Minat Beli. Sedangkan sisanya $(100 \%-51.84 \%=$ 48,16\%), maka sebesar 48,16\% lainnya dipengaruhi oleh faktor-faktor lain yang tidak dibahas dalam penelitian ini. 


\section{Regresi Linier Sederhana}

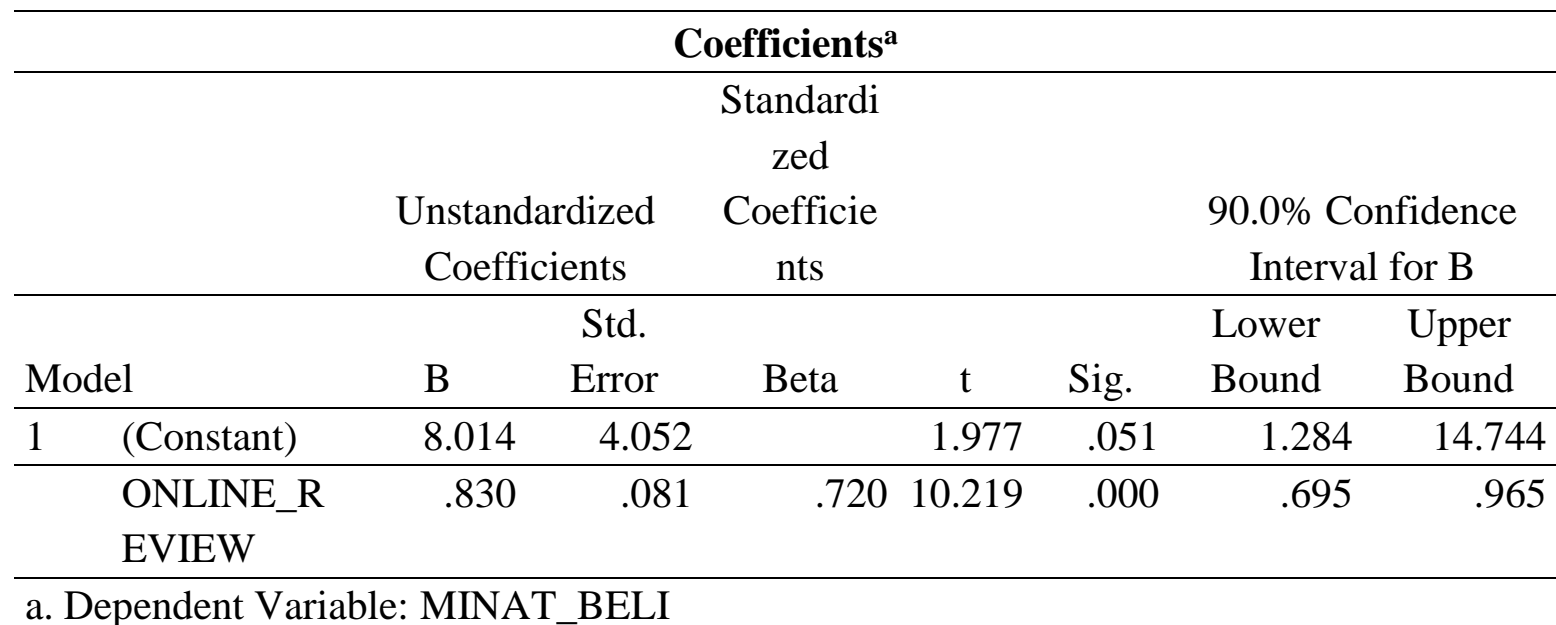

Sumber: olahan data peneliti, 2019

Hasil dari tabel tersebut menggambarkan regresi linear sederhana antara variabel Online Review terhadap Minat Beli dengan persamaan sebagai berikut:

$$
\mathrm{Y}=8,014+0,830
$$

Dari persamaan diatas, dapat dijelaskan bahwa nilai regresi dari online reviewsebesar 0,830 dapat diartikan setiap kenaikan satuan penilai dari responden terhadap minat beli maka akan meningkatkan keputusan pembelian sebesar 0,830 . Jika variabel online review semakin meningkat maka akan semakin meningkatkan variabel minat beli sebaliknya jika variabel online review menurun maka akan menurunkan variabel minat beli.

Uji T (Partial)

\section{Coefficients $^{\mathrm{a}}$}

$\begin{array}{cc}\begin{array}{c}\text { Unstandardized } \\ \text { Coefficients }\end{array} & \begin{array}{c}\text { Standardized } \\ \text { Coefficients }\end{array}\end{array}$

\begin{tabular}{|c|c|c|c|c|c|c|}
\hline Model & & B & Std. Error & Beta & $\mathrm{t}$ & Sig. \\
\hline 1 & (Constant) & 8.014 & 4.052 & & 1.977 & .051 \\
\hline & $\begin{array}{l}\text { ONLINE_REVI } \\
\text { EW }\end{array}$ & .830 & .081 & .720 & 10.219 & .000 \\
\hline
\end{tabular}

Sumber: olahan data peneliti, 2019

Dalam pengujian uji T dapat dilihat apakah variabel bebas secara langsung mempengaruhi variabel terikat ditentukan signifikasi dengan membandingkan $\mathrm{T}$ hitung dengan $\mathrm{T}$ tabel. Untuk uji hipotesis :

Apabila $\mathrm{T}$ hitung $<\mathrm{T}$ tabel $:$ maka $\mathrm{H}_{\mathrm{O}}$ diterima dan $\mathrm{H}_{\mathrm{a}}$ ditolak sehingga variabel $\mathrm{X}$ tidak mempengaruhi variabel $\mathrm{Y}$.
Apabila $\mathrm{T}_{\text {hitung }}>\mathrm{T}_{\text {tabel }}$ : maka $\mathrm{H}_{\mathrm{O}}$ ditolak dan $\mathrm{H}_{\mathrm{a}}$ diterima sehingga variabel $\mathrm{X}$ mempengaruhi variabel Y.

Untuk mencari $\mathrm{T}$ tabel dapat menggunakan rumus berikut :

Jumlah sampel yang digunakan $(\mathrm{n})=100$ dan jumlah variabel $(\mathrm{k})=2$

Rumus : df $1=\mathrm{k}-1$, maka df $1=2-1=1$ 


$$
\mathrm{df} 2=\mathrm{n}-\mathrm{k}, \text { maka df2 }=100-1=99
$$

Dalam pengujian ini dilakukan taraf signikasi pada $\alpha=10 \%$, nilai $\mathrm{T}$ tabel sebesar 1,66. Maka dapat dilihat dari tabel diatas bahwa $\mathrm{T}_{\text {hitung }}(1,977)>\mathrm{T}_{\text {tabel }}(1,66)$ dapat dinyatakan $\mathrm{H}_{\mathrm{o}}$ ditolak dan $\mathrm{H}_{\mathrm{a}}$ diterima yang berarti bahwa online review berpengaruh terhadap minat beli Hotel Manhattan.

\section{KESIMPULAN}

Berdasarkan uraian dan pembahasan pada bab-bab sebelumnya mengenaiAnalisis Online Review Tripadpadvisor.comterhadap Minat Beli produk jasa Akomodasi Manhattan Hotel Jakarta, maka langkah terakhir dari penulisan proyek akhir ini adalah menjabarkan kesimpulandari analisa data penelitian.

Dapat diketahui bahwa review online mempunyai pengaruh yang positif terhadap minat beli. Berdasarkan pembahasan penelitian dapat diambil kesimpulan bahwa:

1. Berdasarkan Hasil Statistik Deskriptif Review Online disimpulkan bahwa Isi dari ulasan / review yang ada di TripAdvisor sangat bermanfaat bagi responden untuk menentukan pilihan menginap serta berpengaruh sangat baik atau kuat kepada para pelanggan untuk melihat review atau ulasan sebagai tolak ukur untuk mentukan pilihan menginap dan Secara keleluruahn rata- rata variable Online Review dengan prosentase 4.13 menurut Sudjana adalah kuat atau baik dalam meberikan informasi kepada pelanggan untuk memilih Manhattan Hotel sebagai salah satu pilihan untuk menginap.

2. Berdasarkan Hasil Statistik Deskriptif Minat Beli disimpulkan bahwa Melalui Tripadvisor, responden dapat membandingkan harga serta kualitas produk Manhattan Hotel menjadi tolak ukur yang besar untuk memakai jasa akomodasi Manhattan Hotel dan Secara keleluruahn rata- rata variable Minat Beli adalah 4.10 menurut Sudjana adalah kuat atau baik dalam minat beli pelanggan untuk di Manhattan Hotel.
3. Dengan hasil koefisien determinasi sebesar 51,80 \% maka review online untuk Manhattan Hotel yang ada di Tripadvisor.com memiliki kontribusi terhadap Minat beli Sedangkan $48,16 \%$ lainnya dipengaruhi oleh faktor-faktor lain yang tidak dibahas dalam penelitian ini.

\section{DAFTAR PUSTAKA}

Creswell, J. W. (2014). Research Design: Qualitative, Quantitative and Mixed Methods Approaches (4th ed.). Thousand Oaks, CA: Sage

Fergian, Yandy. (2018). PENGARUH ONLINE REVIEW DALAM TRIPADVISOR TERHADAP KEPUTUSAN MENGINAP PENGUNJUNG PADA SWISSBELHOTEL BORNEO DI SAMARINDA. Diakses dari https://ejournal.adbisnis.fisipunmul.ac.id/site/?p=1802

Debora, Yantina. (05 Desember 2016). Berapa Besar Pengaruh Ulasan Pembeli Saat Belanja Online. https://tirto.id/berapabesarpengaruh-ulasan-pembelisaatberbelanja-online-b7Gm diakses pada tanggal 26 Agustus 2019 pukul 08:25 WIB

Peterson, R.A., \& Merino, M.C. (2003). Consumer information search behavior and the Internet. Psychology \& Marketing, 20(2), 99121.

Reviewtrackers.com. N.d. Online Review Survey. https://www.reviewtrackers.com/re ports/online-reviews-survey/ diakses pada 23 Juni 2019 pukul 23:17 WIB

Samuel, Hatane \& Lianto, Adi Suryanata. (2014). ANALISIS eWOM, BRAND IMAGE, BRAND TRUST DAN MINAT BELI PRODUK SMARTPHONE DI SURABAYA. JURNAL MANAJEMEN PEMASARAN, Vol. 8, No. 2, 
Oktober $2014 . \quad$ doi:

10.9744/pemasaran.8.2.47-54

Sugiarto, Eko. (2015). Menyusun Proposal Penelitian Kualitatif Skripsi dan Tesis. Yogyakarta: Suaka Media.

Sugiyono. (2004). Metode Penelitian Bisnis, Cetakan Keenam. Bandung: PT. Alfabeta.

(2015). Metode Penelitian Kombinasi (Mix Methods).

Bandung: PT. Alfabeta.

(2016). Metode Penelitian Kuantitatif, Kualitatif dan R\&D. Bandung: PT Alfabeta.

(2017). Metode Penelitian Kuantitatif, Kualitatif, dan R\&D. Bandung: PT. Alfabeta.

Wawancara Eva Juwita,Head of SalesMICE Manhattan Hotel, 2018 